University of Nebraska - Lincoln

DigitalCommons@University of Nebraska - Lincoln

2008

\title{
A New Holcocera Clemens, 1863 (Lepidoptera: Coleophoridae) Associated with Leguminous Plants from the Brazilian Cerrado
}

\author{
David Adamski \\ Department of Entomology, National Museum of Natural History, Smithsonian Institution, P.O. Box 37012, \\ MRC 168, Washington, D.C., 20013- 7012, U.S.A., adamskid@si.edu \\ Cibele S. Ribeiro-Costa \\ Departmento de Zoologia, Universidade Federal do Parana', Caixa Postal 19020, 81513-980, Curitiba, \\ Parana', Brazil, stra@ufpr.br
}

Follow this and additional works at: https://digitalcommons.unl.edu/systentomologyusda

Part of the Entomology Commons

Adamski, David and Ribeiro-Costa, Cibele S., "A New Holcocera Clemens, 1863 (Lepidoptera: Coleophoridae) Associated with Leguminous Plants from the Brazilian Cerrado" (2008). USDA Systematic Entomology Laboratory. 47.

https://digitalcommons.unl.edu/systentomologyusda/47

This Article is brought to you for free and open access by the Entomology Collections, Miscellaneous at DigitalCommons@University of Nebraska - Lincoln. It has been accepted for inclusion in USDA Systematic Entomology Laboratory by an authorized administrator of DigitalCommons@University of Nebraska - Lincoln. 


\title{
A NEW HOLCOCERA CLEMENS, 1863 (LEPIDOPTERA: COLEOPHORIDAE) ASSOCIATED WITH LEGUMINOUS PLANTS FROM THE BRAZILIAN CERRADO
}

\author{
David Adamski and Cibele S. Ribeiro-Costa
}

(DA) Department of Entomology, National Museum of Natural History, Smithsonian Institution, P.O. Box 37012, MRC 168, Washington, D.C., 200137012, U.S.A. (e-mail: david.adamski@ars.usda.gov); (CSRC) Departmento de Zoologia, Universidade Federal do Paraná, Caixa Postal 19020, 81513-980, Curitiba, Paraná, Brazil (e-mail: stra@ufpr.br)

Abstract.-Holcocera cerradicola, n. sp., is described from the Brazilian cerrado in Paraná. Adults were obtained from field-collected larvae from fruits of two leguminous plant species, Bauhinia holophylla Steud (Caesalpinioideae) and Stryphnodendron adstringens (Mart.) Coville (Mimosoideae). These observations represent the first documented association between Holcocerini and Leguminosae. A photograph of the holotype and illustrations of wing venation and male and female genitalia are provided.

Key Words: Brazil, cerrado, legumes, Neotropics, savanna, taxonomy

Except for Amazonia, the cerrado is Brazil's largest biome. This vast savanna once extended over 2 million $\mathrm{km}^{2}$, about one fourth of the country's land area (Oliveira-Filho \& Ratter 1995), but is now reduced to $356,630 \mathrm{~km}^{2}$, or about $20 \%$ of its estimated original size (Da Fonseca et al. 2000). The primary reason for the reduction of this large savanna is increased agricultural pressure exerted by soybean, cotton, and cattle farmers (Dias 1990, Scariot et al. 2005).

The cerrado occupies most of the Central Plain of Brazil, a major portion of the states of Tocantins, Goiás, Mato Grosso do Sul, Mato Grosso, Minas Gerais, Bahia, Maranhão, Piauí, and parts of São Paulo, Pará, Roraima, Amapá, and Rondônia, and extends marginally into eastern Paraguay (Mantovani and Pereira 1998). Despite its reduction in size, it remains the largest woodland savanna region in South America and sustains some of the richest savanna flora in the world.

Nearly 6,500 plant species have been recorded from the cerrado (Mendoça et al. 1998), including about $44 \%$ of all the endemic vascular plants known from Brazil (Silva and Bates 2002). This is one of the major reasons the Brazilian Cerrado is considered one of the top 25 conservation "hotspots" in the world (Myers et al. 2000).

In Paraná, the remnant cerrado is fragmented (Ferri 1979, Uhlmann et al. 1998) and is similar to the savanna areas in other parts of the country, differing only by higher pluviometric indices, evenly distributed rains throughout the year, and a mean temperature of about $15^{\circ} \mathrm{C}$ (Leite 2002).

In the savanna, studies of fruits provide valuable information on associ- 
ations between various plant species and vertebrate and invertebrate life. Fruits contain a higher level of energy per unit area than other plant parts and are essential elements for plant reproduction. Insects that feed on fruits and their seeds can be key factors affecting the dynamics, distribution, and evolution of plants in the savanna (Zhang et al. 1997). However, little is known about the insect fauna, their hosts, and their predator and parasite complexes in the Brazilian Cerrado, and studies of this kind have not been undertaken in this region until recently.

Studies focusing on the interactions between the insect fauna associated with leguminous fruits in the Brazilian Cerrado were initiated in Paraná in 2003 at The Parque Estadual do Cerrado located in Jaguariava County $\left(24^{\circ} 09^{\prime} \mathrm{S}\right.$, $50^{\circ} 18^{\prime} \mathrm{W}$ ) in southern Brazil. The park covers an area of 426.62 ha and protects some of the last remnants of the cerrado vegetation in Paraná (Uhlmann et al. 1998). It contains both forest and grassland.

Among the many insects reared from fruits of legumes during this study were several specimens of microlepidoptera, including a new species of Holcocera (Coleophoridae: Blastobasinae), which is described herein to make its scientific name available for inclusion in a list of insects associated with plants of the Brazilian cerrado.

Holcocera is represented by about 70 species worldwide, and its center of diversity is in the New World tropics. The genus is characterized by having the ventrolateral margins of the gnathos fused with the tegumen, an aedeagus with a multisetose anellus, and proximal flange of the valva with a pointed apex. Although many undescribed Holcocera are represented in major institutional and in private collections, undoubtedly, more species will be obtained through future efforts of collectors, especially in tropical regions worldwide. Several host relationships are known for the genus. For example, Holcocera gigantella Chambers and $H$. paradoxa Powell feed on seeds and pods of Yucca spp. (Liliaceae); $H$. chalcofrontella feed on the seeds of Rhus sp. (Anacardiaceae); H. panurgella Heinrich and $H$. vilella (Busck) feed on the seeds of pine (Pinaceae); and several undescribed species (Adamski and Brown 1989) are associated with plants within the Fagaceae, Rosaceae, Solanaceae, Salicaceae, and a fungus within Polyporaceae. In addition, several species of Holcocera are known scavengers and/or predators, feeding on scales and aphids, while some species are either gall inducers or secondarily associated with galls.

In describing the new species, the gross morphological observations and measurements of the adult vestiture were made using a dissecting microscope (deflected light) with a calibrated micrometer. The Methuen Handbook of Colour (Kornerup and Wanschner 1978) was used as a color standard. Genitalia were dissected as described by Clarke (1941) except that mercurochrome and chlorazol black were used as stains. Pinned specimens and genital preparations were examined with dissecting and compound microscopes respectively. Wings were prepared cleared and drymounted on slides following Borror, Delong and Triplehorn (1981), except glass slide covers were used instead of "masks" to protect the specimens. Measurements of the wings were made using a calibrated ocular micrometer. The holotype is deposited in the Coleço de Entomologia Pe. Jesus Santiago Moure, Departmento de Zoologia, Universidade Federal do Paraná (DZUP), Curitiba, Paraná, Brazil. Paratypes are deposited in the DZUP and the National Museum of Natural History (USNM), Smithsonian Institution, Washington, DC, USA. Each specimen deposited in DZUP is labeled with a museum accession num- 


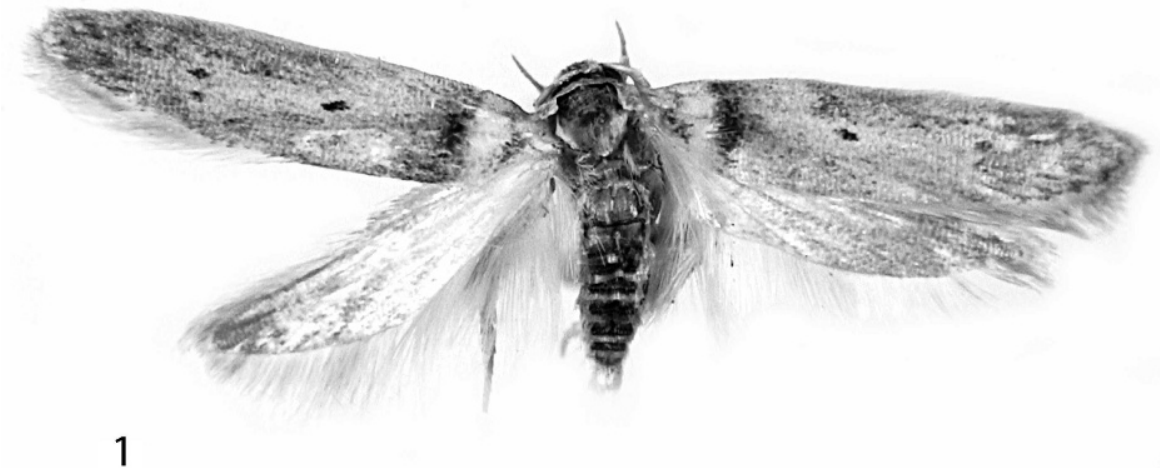

Fig. 1. Holotype $\delta$, of Holcocera cerradicola.

ber. Placement of plant species within the family Leguminosae follows Wojciechowski et al., (2004).

\section{Holcocera cerradicola, Adamski and Ribeiro-Costa, new species}

(Figs. 1-5)

Diagnosis.-Holcocera cerradicola is similar to $H$. bucinae Adamski (2002) from Costa Rica by sharing a raised basal fascia of the forewing, a basal process near the dorsal articulation of the valva, and an elongate anellus of the aedeagus; it differs from the latter by having a wider gnathos, a more protuberant basal process near the dorsal articulation of the valva, an emarginate ventral margin of the juxta, a smaller proximal flange, and a uniformly curved internal sclerite of the aedeagus.

Description.-Head: Scales of vertex and frontoclypeus brownish gray tipped with pale brownish gray; outer surface of labial palpus with gray scales tipped with white, inner surface as above but darker or first and second articles as above and third article gray; scape of antenna gray intermixed with pale-gray scales, pecten pale gray, flagellum gray; first flagellomere widened basally, forming a flattened lobe with a dense cluster of sex scales on inner surface in male, unmodified in female; proboscis pale gray.
Thorax: Tegula and mesonotum dark brownish gray basally, brownish distally with scales tipped with white. Legs with dark brownish gray intermixed with few scales tipped with white, all segments with a band of pale brownish-gray scales at base, near middle, and at distal end; tarsomeres dark brownish gray with a narrow band of brownish-gray scales distally. Forewing (Figs. 1-2) length 7.2-9.2 $\mathrm{mm}(\mathrm{n}=9)$, pale brownish gray intermixed with dark brownish-gray scales and scales tipped with white; base with a narrow band of raised pale brownish gray and raised dark brownish scales; cell with 3 small dark brownish-gray spots, one near midcell and two near distal end; marginal spots present or absent. Undersurface brown. Venation with $\mathrm{R}_{4}$ and $\mathrm{R}_{5}$ stalked near distal end; $\mathrm{M}_{2}$ closer to $\mathrm{M}_{3}$ than to $\mathrm{M}_{1} ; \mathrm{CuA}_{1}$ closer to $\mathrm{M}_{3}$ than to $\mathrm{CuA}_{2}$; retinaculum with setae on bases of $\mathrm{Sc}$ and radius. Hindwing (Figs. 1-2) translucent near base, gradually darkening to brown apex. Venation with cubitus 4-branched, with $\mathrm{M}_{2}$ broadly arched from base, $\mathrm{M}_{3}$ and $\mathrm{CuA}_{1}$ straight and divergent from bases, and $\mathrm{CuA}_{2}$ beyond middle of cell.

Abdomen: Terga 2-7 with several, irregular rows of spinelike setae in male, setae on terga 2-6 in female. 


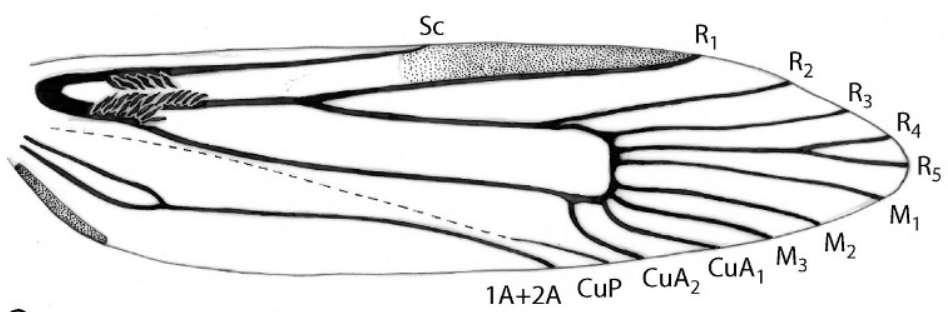

2
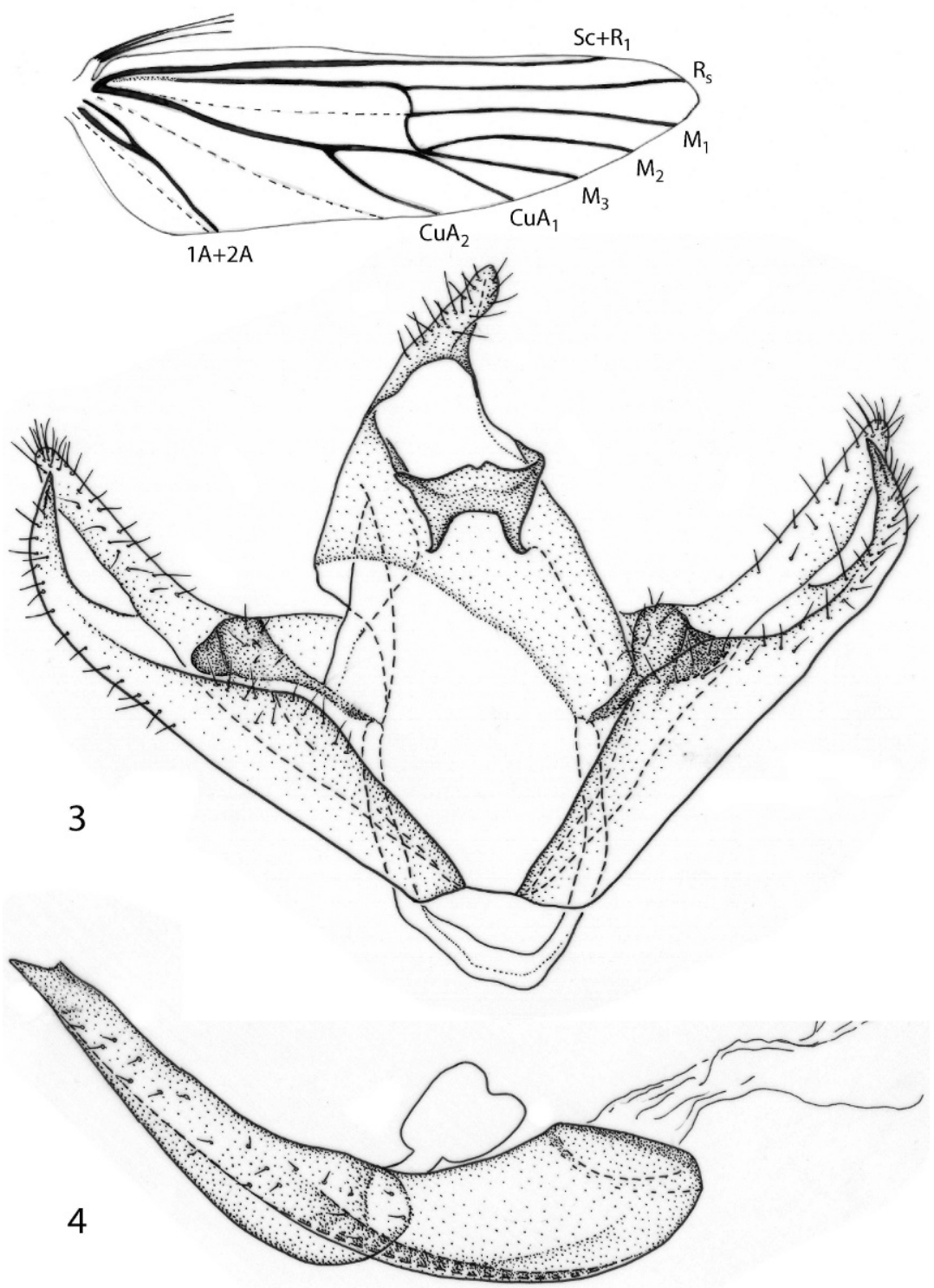

Figs. 2-4. Holcocera cerradicola. 2, Wing venation. 3, Genital capsule. 4, Aedeagus. 


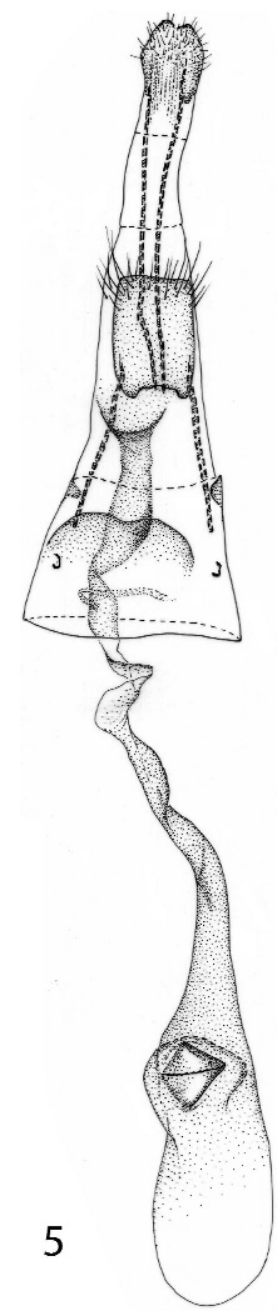

Fig. 5. Female genitalia of Holcocera cerradicola.

Male genitalia (Figs. 3-4): Uncus sparsely setose, slightly elongate, gradually tapering to a rounded apex; gnathos weakly fused to tegumen by a pair of dorsoposterior and ventroanterior arms, ventroposterior margin slightly emarginate medially; vinculum narrow; juxta emarginate ventrally; valva with a digitate upper part; lower part relatively broad, distally produced into an upturned spinelike process; valva with a large lobelike process near dorsal articulation; proximal flange large, sparsely setose apically; aedeagus widened basally, gradually narrowing to apex; internal sclerite of aedeagus fused with base of anellus; anellus pointed apically, with many microsetae.

Female genitalia (Fig. 5): Ovipositor with 3 telescopic subdivisions posterior to eighth segment; eighth sternum setose on distal third, broadly emarginate along anterior margin; lower part of ostium demarcated by a narrow, semicircular rim; antrum sparsely spinulate, slightly widened anteriorly, with small, darkly pigmented area posterior to inception of ductus seminalis; anterior part of ductus bursae sparsely spinulate, with spinulation continuing into corpus bursae; corpus bursae with a large diamond-shaped signum; signum slightly spinulate, with a slightly raised, transverse ridge.

Types.-Holotype: §े, "Jaguariava, Paraná, Brasil, 13-XI-2003, Sari, L.T., Leg."; "Stryphnodendron adstringens, Cerrado, sensu stricto (CSS)"; "D. Adamski o Genitalia Slide No. 5660" [yellow label], "DZ 10.223". Deposited in DZUP.

Paratypes (3 $\delta, 6$ ㅇ): Same label data as holotype except, 1 1 , "2-XII-2003”; "Campo Cerrado"; " o Genitalia Slide by DA, USNM 83233” [green label]; 1 ㅇ, “3X-2003”; "Campo Cerrado"; "o Genitalia Slide by DA, USNM 83235"; 1 ㅇ, "7X-2003”; "Campo Cerrado"; "o Genitalia Slide by DA, USNM 83234"; 1 ๙ , 1 ㅇ, "18-XI-2003"; "Campo Cerrado"; “冬 Genitalia Slide by D. Adamski, No. 5661" [yellow label], "DZ 10.099"; "Sample 2"; "q Genitalia Slide by DA, USNM 83236”; 1 q, “25-X-2003”; "Campo Cerrado"; "q Genitalia Slide by D. Adamski, No. 5662" [yellow label], "DZ 10.030"; 1 ․, "2-XII-2003"; "Campo Cerrado"; "Sample 2"; "q Genitalia Slide by D. Adamski, No. 5663a," "q Wing Slide by D. Adamski, No. 5663b" [yellow labels], "DZ 10.478"; 1 , "9-I2004”; "Bauhinia holophylla, Campo sujo, (CS)"; "ㅇ Genitalia Slide by D. Adamski, No. 5664" [yellow label], "DZ 10.477". 
Four paratypes in DZUP, 4 paratypes in [USNM].

Hosts.-Bauhinia holophylla Steud (Caesalpinioideae: Leguminosae) and Stryphnodendron adstringens (Mart.) (Mimosoideae: Leguminosae).

Etymology.- The species epithet "cerradicola" is derived from the root "cerrado," the habitat from where the type series was collected, and the Latin suffix, -cola, meaning "inhabitant of."

\section{AcKnowledgments}

We thank James F. DiLoreto, Office of Imaging and Photographic Services, Smithsonian Institution, Washington, D.C., for the digital processing and preparation of the plates, and Diana Marques of Portugal for the fine illustrations of the male and female genitalia. This research was sponsored by the Conselho Nacional de Desenvolvimento Científico e Technológico (CNPq) and represents contribution no. 1714 of the Departmento de Zoologica, Universidade Federal do Paraná, Curitiba, Brazil.

\section{Literature Cited}

Adamski, D. 2002. Holcocerini of Costa Rica (Lepidoptera: Gelechioidea: Coleophoridae: Blastobasinae). Memiors of the Entomological Society of Washington, No. 24. 147 pp.

Adamski, D. and R. L. Brown. 1989. Morphology and Systematics of North American Blastobasidae (Lepidoptera: Gelechioidea). Mississippi Agricultural \& Forestry Experiment Station Technical Bulletin 165, Mississippi Entomological Museum no. 1, 70 pp.

Borror, D. J., D. M. Delong, and C. A. Triplehorn. 1981. An Introduction to the Study of Insects. 5th edition. CBS College Publishing, Philadelphia, $\mathrm{Pa}, 928$ pp.

Clarke, J. F. G. 1941. The preparation of slides of the genitalia of Lepidoptera. Bulletin of the Brooklyn Entomological Society 36: 149-161.

Da Fonseca, G. A. B., R. Cavalcanti, A. Rylands, and A. Paglia. 2000. Cerrado. In Hotspots Revisited: Earth's Biologically Richest and Most Endangered Terrestrial Ecoregions. Conservational International, $392 \mathrm{pp}$.
Dias, B. F. S. 1990. Conservaço da natureza do Cerado brasileiro, pp. 583-640. In Pinto, N. ed. Cerrado: Caracterizaço, Ocupaço e Perspectivas. Ed. Universidade de Brasília, 667 pp.

Ferri, M. G. 1979. Uma década 1968-1977 de trabalhos no cerrado, pp. 23-59. In Goodland, R. and M. G. Ferri, eds. Ecologica do Cerrado. Itatiaia, EDUSP, São Paulo, 193 pp.

Koenerup, A. and J. H. Wanschner. 1978. Metheun Handbook of Colour. 2nd ed. Methuen and Co., Ltd., London, 234 pp.

Leite, P. F. 2002. Contribuiço ao conhecimento fitoecológico do Sul do Brasil. Cincia e Ambiente 24: 51-73.

Mantovani, J. E. and A. C. Pereira. 1998. Estimativa da integridade da cobertura vegetal do cerrado através de dados TM/Landsat, pp. 1455-1466. In Simpósio Brasileiro de Sensoriamento Remoto, 9, Santos - SP. So José dos Campos-SP: Instituto Nacional de Pesquisas Espaciais.

Mendonça, R., J. M. Felfili, B. M. T. Walter, M. C. Silvia Júnior, A. V. Rezende, T. S. Filgueiras, and P. E. N. Nogueira. 1998. Flora vascular do Cerrado, pp. 287-556. In Sano, S. and S. S. Almeida, eds. Cerrado: Ambiente e Flora. EMBRAPA-CPAC, Planaltina, 555 pp.

Myers, N., R. A. Mittermeier, C. G. Fonseca, G. A. B., and J. Kent. 2000. Biodiversity hotspots for conservation priorities. Nature 403: 853-858.

Oliveira-Flilho, A. T. and J. A. Ratter. 1995. A study of the origin of central Brazilian forests by the analysis of plant species distribution patterns. Edinburgh Journal of Botany 52(2): 141-194.

Scariot, A., J. C. Souza-Silva, and J. M. Felfili. 2005. Introduço, pp. xi-xii. In Scariot, A., J. C. Souza-Silva, and J. M. Felfili, eds. Cerrado: Ecologia, Biodiversidade e Conservaço. Ministério do Meio Ambiente, Brasília, 439 pp.

Silva, J. M. C. and J. M. Bates. 2002. Biogeographic patterns and conservation in the South American Cerrado: a tropical savanna hotspot. Bioscience 52: 225-233.

Uhlmann, A., F. Galvo, and S. M. Silva. 1998. Anlse da estrutura de duas unidades fitofisionômicas de savana (cerrado) no sul do Brasil. Acta Botanica Brasilica 12(3): 231-247.

Wojciechowski, M. F., M. Lavin, and M. J. Sanderson. 2004. A phylogeny of legumes (Leguminosae) based on analysis of the plastid matK gene resolves many well-supported subclades within the family. American Journal of Botany 91: 1846-1862.

Zhang, J., F. A. Drummond, M. Liebman, and A. Hartke. 1997. Insect predation of seeds and plant population dynamics. Technical Bulletin of the Maine Agricultural and Forest Experiment Station 163: 1-125. 